\title{
The Development of Semiotic Based Contextual Mathematics Learning Videos to Support Learning from Home
}

\author{
Mu'jizatin Fadiana ', Yulaikah ${ }^{2}$, Diah Kusumawati 3 \\ DOI: $10.35445 /$ alishlah.v13i1.372
}

\section{Article Info}

Keywords:

Mathematics Learning

Video

Contextual Learning

Semiotic

\begin{abstract}
This study aims to develop a contextual mathematics learning video based on semiotics that supports learning from home. This type of research is development research using a 4-D model, which is modified into three stages, namely define, design, and develop. The research subjects were grade $6^{\text {th }}$ elementary school students in Tuban, East Java. In the defined stage, a needs analysis is carried out as a reference for development. The design stage produces research instruments and instructional video designs. The development stage states that based on the results of the validation of media experts by $85 \%$ and material experts by $87 \%$, each of which comes from 21 points of assessment indicators, it shows that it meets the valid criteria as well as positive responses of $85.3 \%$ of 28 students. The right-hand t-test obtained $t$-count $>t$-table, namely 3.886> 1.675. It indicates that the learning outcomes of students who use semiotic-based contextual mathematics learning videos on the perimeter of circle material are better than students who do not use them. This learning video has reached effective criteria.
\end{abstract}

Kata kunci:

Video Pembelajaran Matematika

Pendekatan Kontekstual Semiotic

\begin{abstract}
Abstrak
Penelitian ini bertujuan untuk mengembangkan video pembelajaran matematika kontekstual berbasis semiotik yang mendukung belajar dari rumah. Jenis penelitian ini merupakan penelitian pengembangan dengan menggunakan model 4-D yang dimodifikasi menjadi tiga tahap yaitu define, design, dan develop. Subjek penelitian adalah siswa Kelas 6 SD. Tahap define, dilakukan analisis kebutuhan yang dijadikan acuan pengembangan. Tahap design, menghasilkan instrumen penelitian dan rancangan video pembelajaran. Tahap develop menyatakan bahwa berdasarkan hasil validasi ahli media sebesar $85 \%$ dan ahli materi sebesar $87 \%$ masing-masing berasal dari 21 butir indikator penilaian menunjukkan bahwa memenuhi kriteria valid serta tanggapan positif sebesar 85,3 \% dari 28 siswa. Uji t pihak kanan didapat $t_{\text {hitung }}>t_{\text {tabel }}$ yaitu 3,886 $>1,675$, menandakan bahwa hasil belajar dari rumah siswa yang menggunakan video pembelajaran matematika kontekstual berbasis semiotik pada materi keliling lingkaran lebih baik daripada siswa yang tidak menggunakannya, sehingga video pembelajaran ini memenuhi kriteria efektif.
\end{abstract}

\footnotetext{
${ }^{1}$ Universitas PGRI Ronggolawe, Tuban, Indonesia Email: mujizatinooo@gmail.com 2 Universitas PGRI Ronggolawe, Tuban, Indonesia Email: juleyulaekah@gmail.com

3 Universitas PGRI Ronggolawe, Tuban, Indonesia Email: kusumawatidiaho21@gmail.com

Vol.13 (1) June, 2021

Received: February 4, 2021; Received in revised form: February 19, 2021; Accepted: February 26, 2021; Available online: March 30, 2021

This is an open access article under a Creative Commons Attribution-NonCommercial-ShareAlike 4.0 International License.
} 


\section{INTRODUCTION}

The world has experienced a long pandemic caused by the novel coronavirus -19. On February 11, 2020, the 2019-novel coronavirus was officially named SARS-CoV-2 by the World Health Organization (WHO), otherwise known as Covid-19 (Gao et al., 2020). Covid-19 not only causes a worldwide health crisis but also affects all areas of life, including education. The Covid-19 pandemic, which is still ongoing today, has led the government to impose distance learning.

However, teachers, parents, and students experience many distance learning obstacles, especially at the primary school level. Teachers have difficulty communicating with parents as partners at home (Anugrahana, 2020). On the other hand, not all parents can accompany their children to study at home. Parents also experience difficulties in understanding lessons and motivating their children when attending learning at home (Anugrahana, 2020). Students find it difficult to concentrate on learning from home, are less motivated, and complain about assigning teacher questions. Learning from home has the potential to increase feelings of stress and saturation due to continuous isolation. Therefore, the Ministry of Education and Culture has provided direction in implementing distance learning using the $5 \mathrm{M}$ principle, namely, humanizing relationships, understanding concepts, building sustainability, choosing challenges, and empowering contexts.

The existence of learning resources that elementary school students in distance learning can use is essential (Anugrahana, 2020). The learning resources must adopt the $5 \mathrm{M}$ principle. Therefore, teachers as educators must respond to the Covid-19 pandemic by innovating through developing creativity in learning. One of the things that teachers can do is develop learning resources that are effective, fun by elementary school students' characteristics. The appropriate learning resource developed by the teacher in distance learning is in the form of learning videos. The use of relevant learning media can provide a particular enthusiasm for students to learn and create fun learning so that learning objectives will be easily achieved (Yoon \& Kim, 2011). Besides, a fun learning process can make it easier for students to increase their learning motivation and learning achievement, especially the cognitive aspects (Indaryati \& Jailani, 2015).

Elementary school students learn more through interaction with the surrounding environment (Suryansah \& Suwarjo, 2016). The selection of learning media will be more meaningful for students if equipped with material, illustrations, and genuine pictures adopted from their environment. Learning mathematics will be significant for students if it links learning with their real-life (Rahayu \& Kholillah, 2018). Learning mathematics using contextual problems, describing and solving contextual problems can increase students' self-confidence and learning (Mu'jizatin Fadiana et al., 2018a). Besides, teachers must also integrate technology with the environment into attractive video media to increase motivation to learn from home (Suryansah \& Suwarjo, 2016).

Semiotics is the study of the production of signs and symbols to communicate information (M. Fadiana et al., 2019). Semiotics is an activity that involves signs, objects, and interpretations (Yang \& Hsu, 2015). The semiotic theory is used as a foundation for developing mathematics teaching materials because we need signs and representations (Suryaningrum et al., 2020). Signs are used to representing abstract mathematical concepts to make them more straightforward (M. Fadiana et al., 2019).

The semiotic theory is used as a foundation for developing mathematics learning videos because we need signs and representations in learning mathematics. Signs are used to representing abstract mathematical concepts to make them more straightforward (Mu'jizatin Fadiana et al., 2018a). The semiotic theory is used as a foundation for developing mathematics teaching materials because we need signs and representations (Suryaningrum et al., 2020). Many researchers have studied semiotics in mathematics learning (Bjuland, 2012; Campos, 2010; Mu'jizatin Fadiana et al., 2018b; Ng \& Sinclair, 2015). From various existing studies, it is stated that reasoning involving all semiotic components can help students understand mathematical concepts. Students' imagination, concentration, and generalization can be built by investigating all the signs (Campos, 2010). 
Therefore, it is necessary to develop a mathematics learning video that can provide natural experiences for students by empowering various symbols to increase student motivation to learn from home. Learning through video increases motivation and cognitive learning outcomes of elementary school students (Suryansah \& Suwarjo, 2016). Contextual mathematics learning videos based on semiotics are mathematics learning videos that link mathematics material to students' realworld situations involving signs, objects and, interpretants. Contextual mathematics learning videos based on semiotics are appropriate for elementary students because linking mathematics material with real-world problems will make it easier for elementary students to learn mathematical concepts. Abstract concepts are easier to understand because they are presented in a concrete, visual and tangible form around them. A semiotic foundation that involves all signs, objects, and interpretants will help elementary students understand mathematical concepts (Mu'jizatin Fadiana et al., 2018a).

\section{METHODS}

The method used in this research is the Research and Development method. Research and development is a research method used to produce specific products and test these products' effectiveness. This study refers to a device development model suggested by Sivasilam Thiagarajan, Dorothy S. Semmel, and Melvyn I. Semmel, namely the Four-D Model or the 4-D Model. In developing this model, the researcher uses a 4-D model modified into three stages: defining, designing, and developing. The dissemination stage was not carried out because this study aimed to create good learning media.

The product developed in this study is a contextual mathematics learning video based on semiotic material around the circle for grade 6 elementary schools used for distance learning. The define stage aims to define the learning requirements, which can later be used as a reference for developing learning videos. This stage includes five main steps: front-end analysis, student analysis, concept analysis, task analysis, and learning objectives. The design stage aims to prepare a prototype of the learning device and consists of four steps: preparing tests, selecting suitable media, selecting formats, and initial design. The design is as in Figure 1.

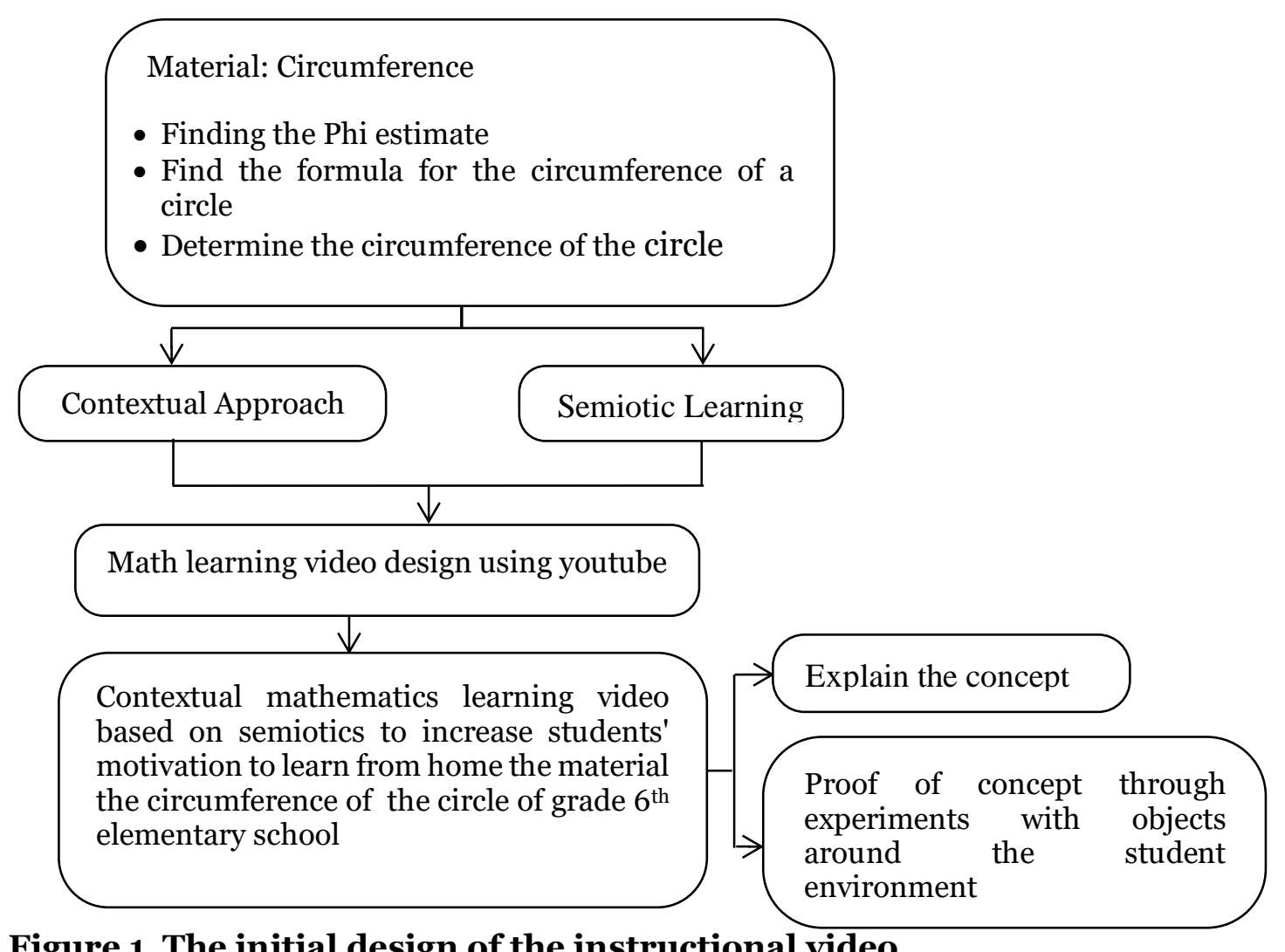

Figure 1. The initial design of the instructional video 
The development stage aims to produce revised learning tools based on expert input. The steps taken at this stage are expert validation and limited trials. In this development, validation is carried out by media experts, material experts, and student responses using a questionnaire. The validation of the mathematics learning video was analyzed with references adapted from the Likert scale. The scale used in this assessment is five scales (Arikunto, 2013: 195)

Table 1. Rankings of the Likert Scale

\begin{tabular}{cc}
\hline Statement & Score \\
\hline Strongly Agree & 5 \\
Agree & 4 \\
Medium & 3 \\
Disagree & 2 \\
Strongly Disagree & 1 \\
\hline
\end{tabular}

After the validation sheet for media experts and material experts is validated by the validator, the validation sheet is analyzed and presented. The percentage can be calculated using the following formula

Information:

$$
P=\frac{\sum(\text { answer } \times \text { weight for each choice })}{n \times \text { highest weight }} \times 100 \%
$$

$\mathrm{P}=$ Percentage

$\mathrm{n}=$ number of all validation sheet items

The percentage that has been obtained then transformed into qualitative sentences. According to Arikunto (Kamelta, 2013), determining the criteria is carried out as in Table 2.

Table 2. Category Value Percentage

\begin{tabular}{ccc}
\hline No & Interval & Criteria \\
\hline 1 & $81 \%-100 \%$ & Very Good \\
2 & $61 \%-80 \%$ & Good \\
3 & $41 \%-60 \%$ & Sufficient \\
4 & $21 \%-40 \%$ & Less \\
5 & $<21 \%$ & Very Less \\
\hline
\end{tabular}

In the validation of media and learning material experts, each item's percentage results are valid if the results obtained are in very good, sound, and sufficient criteria.

The research was conducted at Bina Anak Sholeh Tuban elementary school. This study's subjects were students of grade $6^{\text {th }} \mathrm{C}$ as the control class without using semiotic-based contextual mathematics learning video media and grade $6^{\text {th }} \mathrm{A}$ as the experimental class using semiotic-based contextual mathematics learning video media. The number of students in the control class is the same as the number of students in the experimental class. There are 26 students as a sample.

To determine the effectiveness of this mathematics learning video, an analysis of the initial and final data was carried out based on limited trials. Initial data were analyzed using the normality test, homogeneity test, and two-mean similarity test (two-party t-test). The final data were analyzed using the normality test, homogeneity test, and the two mean similarity tests (proper side t-test). After 
that, the individual learning completeness test and classical learning completeness test were conducted. Students are said to have completed individual learning if they have obtained a value $\geq$ of the minimum completeness criteria. If students have mastered at least $75 \%$ of the material for each proposed discussion unit, the student is said to be complete individually. Group completeness is achieved when $75 \%$ of the total students reach the complete score.

\section{FINDINGS AND DISCUSSION}

Write down the results of your research in this section. Then, you can discuss each aspect of the problem one by one. It is necessary to create arguments and provide original data discussed and compared to other researchers' research and works. In other words, the way to discuss the problem here is to combine data and discussion. Thus, it is not advisable to separate the data description and its analysis.

In this study, the development model refers to the 4-D model modified into three stages: defining, designing, and developing.

\section{Define Stage}

Front-end analysis was carried out through observation and interviews with the 6th-grade teacher of Bina Anak Sholeh Tuban elementary school. Researchers get some information about common problems that occur in distance learning. Including learning resources used by students to learn from home, only printed books, teaching media used in the form of powerpoints, there has been no innovation in other learning media. Students need an explanation from the teacher, like face-to-face learning in class. Parents cannot assist students in learning from home. As a result, student learning motivation is low (Nurniawan, 2013). The economic condition of the parents of the elementary school students of Bina Anak Sholeh Tuban is classified as middle and high. In general, they have complete long-distance communication facilities, such as android phones and subscribing to wifi.

Student analysis was carried out through interviews with mathematics subject teachers. It was obtained information that students were in a concrete thinking stage and preferred to learn with objects around them. For this reason, students need the help of instructional media that can visualize something abstract to be more concrete and closer to students' daily lives.

Concept analysis is carried out through the study of the concepts to be taught in the learning process. This analysis aims to identify, detail, and systematically arrange the concepts to be taught based on the front-end analysis. Based on the emergency 2013 curriculum, the learning video's essential competencies are the material around the circle.

Task analysis is intended to identify skills possessed by students that will be developed in learning. Based on student analysis and concept analysis, the tasks carried out by students during the learning process are applying the concept of circumference in solving daily life problems, determining the value of phi, determining the length of the diameter or radius of a circle. In the next step, the formulation of the task analysis results and analysis of the above concepts is carried out to achieve learning outcomes.

\section{Design Stage}

The test preparation is used as a measuring tool to determine students' abilities after the learning process. In this study, the researcher arranged a final test given to students to determine student learning outcomes after using the developed mathematics learning videos. The test questions are arranged in the form of a description adjusted to the question grid and refer to the questionmaking indicators and scoring guidelines. The basis for preparing the test is to analyze the task and analyze the concepts formulated in the learning objectives specification. In the next step, the researcher selects and determines the appropriate media for the presentation of learning material 
that is adjusted to task analysis, concept analysis, student characteristics, and the presence of school facilities.

Based on this analysis, the learning media chosen to be developed is a semiotic contextual mathematics learning video based on the material perimeter of the circle of grade 6 elementary schools. The choice of format in the developed mathematics learning video is designed systematically. In the form of an introduction, content, practice questions, and a summary of the material with an attractive appearance so that students can focus on explaining the learning video presented and at the same time can be used for independent learning. The initial design of the mathematics learning video developed consists of the following components: 1) the start page of the video; 2) the opening of the video, which consists of opening greetings, motivation, delivery of essential competencies, indicators and learning objectives; 3) explain the concept; 4). Proving concepts through experimenting with objects around the house; 5). sample questions and their solutions; 7) presentation of practice questions; 8) presentation of a summary of the material that has been studied; 9) closing video.

\section{Development stage}

The development stage consists of three steps, namely validation, product testing and effectiveness testing. Validation is an assessment given to a product that a researcher has designed to get suggestions and comments to improve so that the product is valid and can be used for research. Validation was carried out by material experts and media experts, each of which consisted of 2 validators.

Validation of media experts and material experts is carried out before the product is tested. Based on the scale conversion specified in the validation sheet questionnaire for media experts and material experts, it is known that the percentages are respectively $85 \%$ and $87 \%$. After being converted to a scale conversion table, the percentages of both are in very good qualifications. According to material experts and media experts, semiotic-based contextual mathematics learning video is feasible to use. The display of the learning video after being revised is based on input from media experts and material experts as follows

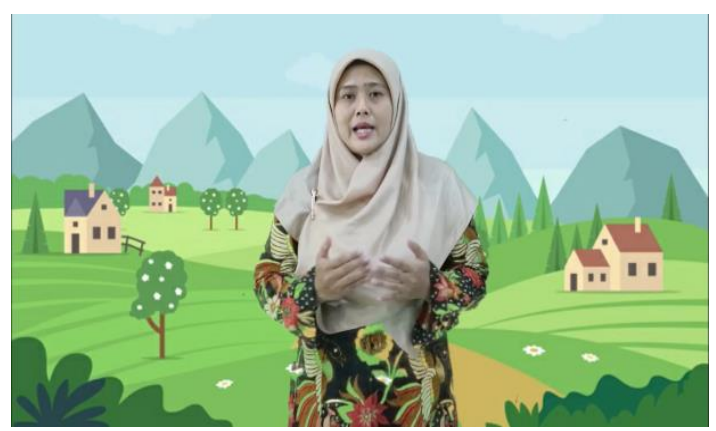

Figure 2. Opening

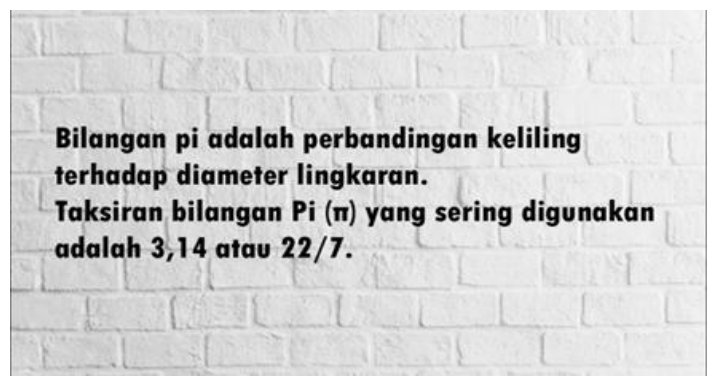

Figure 4. Explaining the Concept Image

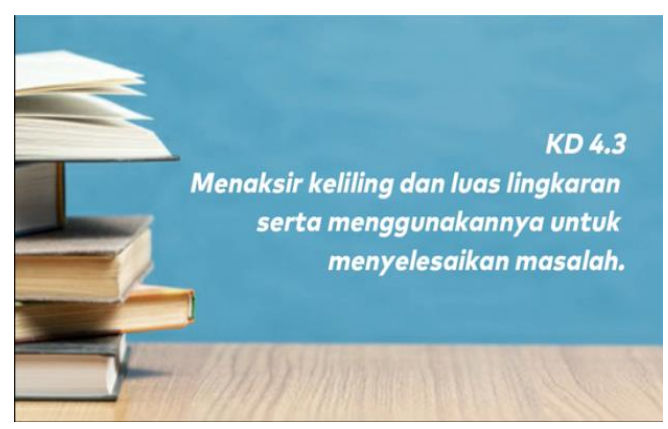

Figure 3. Delivery of Basic Competencies

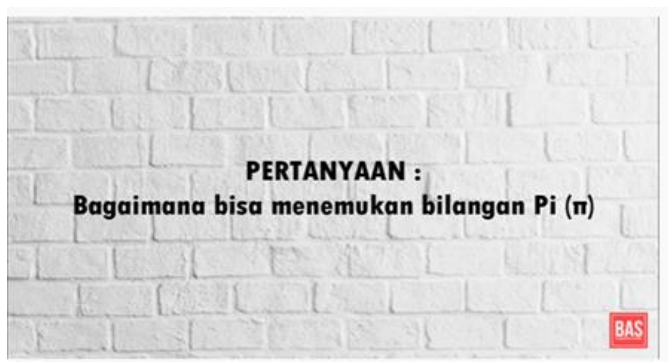

Figure 5. Ask questions to arouse curiosity 


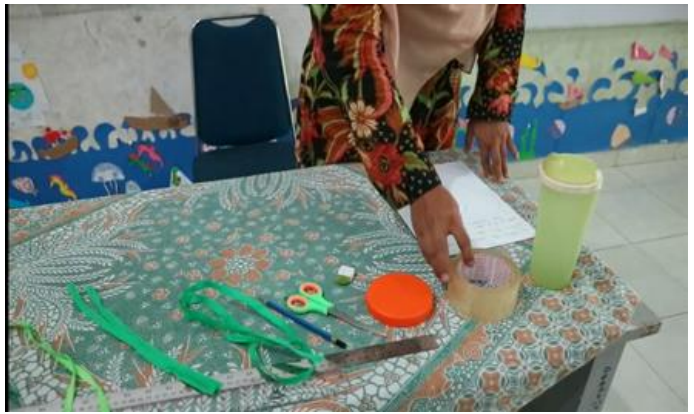

\section{Figure 6. Proving the concept by experimenting with objects around the student's environment}

After getting a proper assessment from material experts and media experts, the distance learning process using the developed mathematics learning video, students' responses to the learning video were taken to assess their feasibility using a student questionnaire. From the student questionnaire results, the results showed that the percentage of positive responses was $85.3 \%$ of the 28 students, including the criteria for being very good and feasible to use.

Furthermore, at the end of the distance learning material around the circle, the experimental and control classes were given post-test questions and student learning motivation questionnaires. From the data, the post-test value is then tested using the normality test, homogeneity test, and the two-mean similarity test (one-party t-test). The normality test shows that the two classes have a normal distribution. The homogeneity test showed that the two classes were homogeneous. Furthermore, the two mean similarity test (right side t-test) show that the t count $>t$ table is 3.256> 1.669 , and $\mathrm{H}_{\mathrm{o}}$ is rejected. Based on the results of the t-test on the right side, it can be seen that the learning outcomes of the experimental class are better than the control class.

The average student learning outcomes using contextual mathematics learning videos based on semiotics on the material perimeter of the circle of grade $6^{\text {th }}$ elementary schools were better than the average learning outcomes of students who did not use instructional videos. Then, based on the experimental class's learning achievement data, the percentage of individual learning outcomes completeness, 26 students completed out of 28 students. At the same time, in the control class, 18 students completed out of 27 students. The results of classical learning completeness in the experimental class were $92.8 \%$, and the follow-up test with the $t$-test resulted in the results of $t_{\text {count }}>$ $t_{\text {table, }}$, namely $3.886>1.675$, then $\mathrm{H}_{\mathrm{o}}$ was rejected. So, it can be concluded that the learning outcomes of the experimental class have achieved classical learning completeness. Then for classical learning completeness in the control class by $66,67 \%$ and the follow-up test with the t-test results obtained $t$ count $<\mathrm{t}_{\text {table, }}$ namely $0.6746<1.796, \mathrm{H}_{\mathrm{o}}$ is accepted. The learning outcomes of the control class have not reached classical learning completeness.

Video learning is a form of media that can bridge teachers so that learning is not conventional (Suryansah \& Suwarjo, 2016). Besides, learning using instructional videos can improve students' understanding of the material provided (Nurdin et al., 2019). There are moving animated images and running text in this video media and interestingly displayed audio (Dewi \& Rimpiati, 2016; Izzudin \& Suharmanto, 2013). There are also simple but interesting symbols and pictures in the video that make it easier for students to understand the material (Ismaili, 2013; Utari \& Nurviyani, 2018). The attractiveness of the developed media attracts students. There are music strains, explanatory sounds and illustrations, and pictures taken from real conditions packaged attractively in the video. 
Contextual mathematics learning video based on semiotics is under the cognitive development of grade $6^{\text {th }}$ elementary school students because they are at a concrete operational stage. They are interested and motivated to learn from home because the material they are learning is around them. Learning for children at the concrete operational stage is carried out using visual aids and involves tangible things found around them (Mayer \& Moreno, 2003). According to media experts' advice, the selection of music is adjusted to elementary school students' characteristics. The music learning video and image display are adjusted according to the input from the media expert. Music under the child's features will generate children's interest in learning videos (Fredy \& Soenarto, 2013; Hidayatulloh, 2017).

\section{CONCLUSION}

Based on the percentage of validation results from media experts, which reached $85 \%$ and the results of validation of material experts which reached $87 \%$ and a positive student response questionnaire of $85.3 \%$, so that the semiotic-based contextual mathematics learning video material around the circle of grade $6^{\text {th }}$ elementary schools reached the valid criteria. The results of limited trials and individual and classical learning completeness stated that the average learning outcomes of students from home using contextual mathematics learning videos based on semiotics, the perimeter of the circle material for grade $6^{\text {th }}$ primary schools is better than the average learning outcomes of students who do not use learning videos.

Based on the research results' conclusions, distance learning media in instructional videos has proven effective in helping elementary school students understand mathematics material. Therefore, other researchers are advised to develop instructional videos for different materials. In addition to creating videos, further researchers can also develop student modules to accompany learning activities from home during the pandemic.

\section{REFERENCES}

Anugrahana, A. (2020). Hambatan, Solusi dan Harapan: Pembelajaran Daring Selama Masa Pandemi Covid-19 Oleh Guru Sekolah Dasar. Scholaria: Jurnal Pendidikan Dan Kebudayaan. https://doi.org/10.24246/j.js.2020.v10.i3.p282-289

Bjuland, R. (2012). The mediating role of a teacher's use of semiotic resources in pupils' early algebraic reasoning. $Z D M$ - International Journal on Mathematics Education. https://doi.org/10.1007/s11858-012-0421-2

Campos, D. G. (2010). Peirce's Philosophy of Mathematical Education: Fostering Reasoning Abilities for Mathematical Inquiry. Studies in Philosophy and Education. https://doi.org/10.1007/s11217-010-9188-5

Dewi, L. M. I., \& Rimpiati, N. L. (2016). Efektivitas penggunaan media pembelajaran video interaktif dengan seting diskusi. Jepun.

Fadiana, M., Amin, S. M., Lukito, A., \& Warli. (2019). How concrete operational student generalize the pattern?: Use semiotic perspective. Journal of Physics: Conference Series. https://doi.org/10.1088/1742-6596/1188/1/012032

Fadiana, Mu’jizatin, Amin, S., \& Lukito, A. (2018a). Profil Generalisasi Berdasarkan Perspektif Semiotik Siswa Operasional Konkret Dan Operasional Formal. JIPMat. https://doi.org/10.26877/jipmat.v3i2.2517

Fadiana, Mu'jizatin, Amin, S. M., \& Lukito, A. (2018b). The Seventh Grade Students' Generalization Strategies of Patterns. Journal of Education and Learning (EduLearn). 
https://doi.org/10.11591/edulearn.v12i3.8997

Fredy, F., \& Soenarto, S. (2013). Pengembangan Multimedia Pembelajaran Matematika Pada Materi Bilangan Bulat Kelas Iv Sdn Lempuyangan I Yogyakarta. Jurnal Prima Edukasia. https://doi.org/10.21831/jpe.v1i2.2633

Gao, Y., Yan, L., Huang, Y., Liu, F., Zhao, Y., Cao, L., Wang, T., Sun, Q., Ming, Z., Zhang, L., Ge, J., Zheng, L., Zhang, Y., Wang, H., Zhu, Y., Zhu, C., Hu, T., Hua, T., Zhang, B., ... Rao, Z. (2020). Structure of the RNA-dependent RNA polymerase from COVID-19 virus. Science. https://doi.org/10.1126/science.abb7498

Hidayatulloh, M. S. (2017). Pengembangan e- modul matematika berbasis problem based learning berbantuan geogebra pada materi bilangan bulat. Aksioma. https://doi.org/10.26877/aks.v7i2.1416

Indaryati, I., \& Jailani, J. (2015). Pengembangan Media Komik Pembelajaran Matematika Meningkatkan Motivasi Dan Prestasi Belajar Siswa Kelas V. Jurnal Prima Edukasia. https://doi.org/10.21831/jpe.v3i1.4067

Ismaili, M. (2013). The Effectiveness of Using Movies in the EFL Classroom - A Study Conducted at South East European University. Academic Journal of Interdisciplinary Studies. https://doi.org/10.5901/ajis.2012.v2n4p121

Izzudin, A. M., \& Suharmanto, A. (2013). Efektivitas Penggunaan Media Pembelajaran Video Interaktif Untuk Meningkatkan Hasil Belajar Praktik Service Engine Dan KomponenKomponennya. Journal Unnes.

Mayer, R. E., \& Moreno, R. (2003). Nine ways to reduce cognitive load in multimedia learning. Educational Psychologist. https://doi.org/10.1207/S15326985EP3801_6

Ng, O. L., \& Sinclair, N. (2015). Young children reasoning about symmetry in a dynamic geometry environment. ZDM Mathematics Education. https://doi.org/10.1007/s11858-014-0660-5

Nurdin, E., Ma'aruf, A., Amir, Z., Risnawati, R., Noviarni, N., \& Azmi, M. P. (2019). Pemanfaatan video pembelajaran berbasis Geogebra untuk meningkatkan kemampuan pemahaman konsep matematis siswa SMK. Jurnal Riset Pendidikan Matematika. https://doi.org/10.21831/jrpm.v6i1.18421

Rahayu, P., \& Kholillah, K. (2018). Validitas Dan Praktikalitas Lembar Kerja Siswa Berbasis Pendekatan Kontekstual Materi Bangun Ruang Sisi Datar Pada Siswa Smp. JIPMat. https://doi.org/10.26877/jipmat.v3i2.2805

Suryaningrum, C. W., Purwanto, Subanji, Susanto, H., Ningtyas, Y. D. W. K., \& Irfan, M. (2020). Semiotic reasoning emerges in constructing properties of a rectangle: A study of adversity quotient. Journal on Mathematics Education. https://doi.org/10.22342/jme.11.1.9766.95-110

Suryansah, T., \& Suwarjo, S. (2016). Pengembangan Video Pembelajaran Untuk Meningkatkan Motivasi Dan Hasil Belajar Kognitif Siswa Kelas Iv Sd. Jurnal Prima Edukasia. https://doi.org/10.21831/jpe.v4i2.8393

Utari, A. N., \& Nurviyani, V. (2018). The Implementation Of Video In Teaching Listening. Jurnal 
JOEPALLT (Journal of English Pedagogy, Linguistics, Literature, and Teaching). https://doi.org/10.35194/jj.v6i1.302

Yang, C.-M., \& Hsu, T.-F. (2015). Applying Semiotic Theories to Graphic Design Education: An Empirical Study on Poster Design Teaching. International Education Studies. https://doi.org/10.5539/ies.v8n12p117

Yoon, J. O., \& Kim, M. (2011). The effects of captions on deaf students' content comprehension, cognitive load, and motivation in online learning. American Annals of the Deaf. https://doi.org/10.1353/aad.2011.0026 